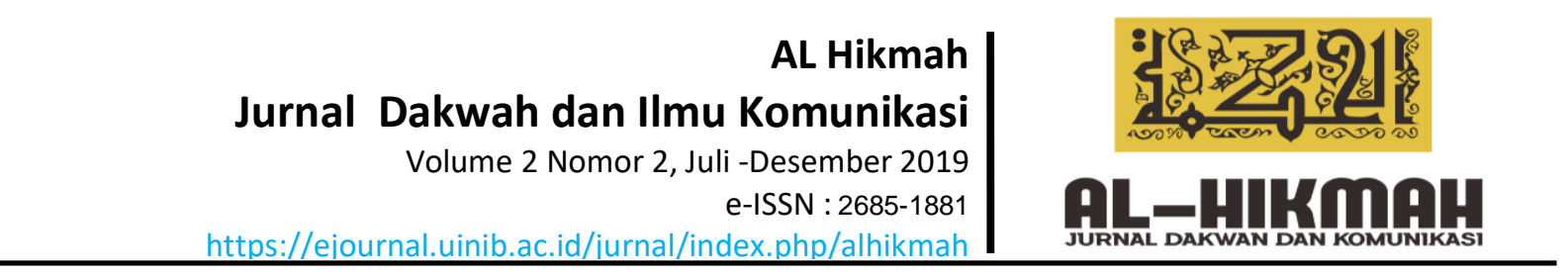

\title{
RETORIKA KHATIB DALAM PENYAMPAIAN KHUTBAH JUM'AT
}

\author{
Luthfi Yuhesdi ${ }^{1}$ \\ Bukhari $^{2}$ \\ Zainal $^{3}$ \\ Sarwan 4 \\ 1 UIN Imam Bonjol Padang \\ Email : Luthfiyuhesdi@gmail.com \\ ${ }^{1}$ UIN Imam Bonjol Padang \\ Email : Bukhari@gmail.com \\ 1 UIN Imam Bonjol Padang \\ Email : Zainal@gmail.com \\ 1 UIN Imam Bonjol Padang \\ Email : Sarwan@gmail.com
}

\begin{abstract}
The background of this research is because of the reality in the field, that the Friday sermon delivered by the khatib has yet to have a good appeal in the sermon. The purpose of this study First is to know how the style of the khatib in the delivery of the Friday sermon, Secondly, to know how the choice of the word of the khatib in the delivery of the Friday sermon, Third, to know how the tone of the khatib in the delivery of Friday sermon, and Fourth, to learn how the sentence structure of the khatib in the delivery of the sermon of Friday. This study uses a qualitative research methodology with observation data collection techniques, and interviews. This study found that the application of rhetoric by the Friday khutib in the sermon had not fully progressed as most khatib had not yet understood rhetoric. This is evident from the diction applied by the khatib not in accordance with the condition of the congregation, the application of repetition of the word does not conform to the rules of repetition. And there's also a lot of words. The relationship between sentence one with another sentence still does not use the correct word. And the emphasis on what matters is still not seen. The intonation conveyed by the khatib has not produced the appropriate variation, then the presentation is still monotonous and creates the jema'ah friday.
\end{abstract}

Keyword : Retorika, Khatib, Khothah Jum'at.

\section{PENDAHULUAN}

Khutbah jumat adalah kegiatan dakwah yang paling efektif yang bertujuan untuk mengajak orang lain untuk meningkatkan kualitas ketaqwaan dengan memberi nasehat yang isinya berupa ajaran agama. Oleh karena itu tidak semua muslim memiliki kemampuan untuk berkhotbah. Menurut Al Ghazali 
seperti dikutip oleh Samsuri Siddiq, khatib adalah para penasehat, para pemimpin dan para pemberi ingat, yang memberikan nasehat dengan baik, yang mengarang dan berkhutbah, yang memusatkan jiwa dan raganya dalam membicarakan kampung akhirat untuk melepaskan orang yang karam dalam gelombang dunia. (Samsuri Shiddiq : 1981)

Memperhatikan penjelasan di atas, kiranya seorang khatib jum'at dalam menyampaikan pesan dakwahnya harus bisa menggunakan retorika yang baik sehingga isi pesan yang disampaikan dapat diterima dan dimengerti oleh mad'unya, dari kacamata ilmu, retorika itu seni kemahiran berbicara. (T.A. Lathief Rousydiy : 2005) Seorang khatib adalah orang yang mahir, ahli berbicara (Zulhasan Latif : 2011) atau berpidato dihadapan umum. Kemahiran dan keahliannya seorang khatib dalam menyampaikan khotbah harus didukung oleh tata bahasa yang baik, lancar, dan benar sehingga dapat mempengaruhi sikap dan perasaan jamaah (Yusuf Zainal Abidin : 2013) yang mendengar khotbah.

Dalam melaksanakan tugas dan tanggung jawab seorang khatib harus mempunyai kemampuan dan pengalaman yang luas serta teruji, agar tugas yang dilaksanakannya bisa berjalan dengan baik dan lancar, sehingga masyarakatnya merasa puas. (Tohir M Natsir : 1999) Hal ini tentu menghendaki bahwa setiap khatib harus memiliki beberapa kemampuan:

a. Kemampuan Berkomunikasi Menurut Samsul Munir kemampuan berkomunikasi tersebut adalah proses bagaimana agar suatu pesan da'i (komunikator) dapat sampai pada komunikan sesuai apa yang diinginkan oleh da'i. (Samsul Munir Amin : 2009)

Kemampuan

berkomunikasi sangat penting bagi setiap manusia, apalagi seorang khatib bagaimana ia cara berdakwah

b. Kemampuan Penguasaan Diri Kemampuan

penguasaan diri yang dimaksud disini karena khatib ibaratkan seorang pemandu, oleh karena itu, sebagai seorang pemandu khatib harus mampu menguasai diri jangan sampai mengesankan sifat sifat sombong, angkuh, kaku, karena sifat tersebut hanya akan menciptakan kerenggangan

$\begin{array}{lrr} & \text { Dari pendapat diatas } \\ \text { dapat diketahui } & \text { bahwa } \\ \text { penguasaan diri } & \text { yang }\end{array}$ dimaksud adalah agar da'i bisa menjaga diri mereka dan sifat sombong, angkuh, dan kaku karena itu semua akan menjauhkan mereka dari mad'u maupun masyarakat banyak.

c. Kemampuan Pengetahuan Psikologis

Maksud dari

kemampuan pemgetahuan psikologis ini adalah dimana seorang khatib harus mampu melihat teman bicara apakah komunikasinya sedih atau gembira, kalau karena seorang da'i berbicara pada kondisi yang tidak sesuai dengan keadaan yang dialami komunikanya bisa saja seorang khatib berbicara sendirian tanpa ada respon dari komunikannya karena pada saat itu komunikan tersebut lagi ada masalah yang 
memungkinkan ia tidak nyambung dengan apa yang dibicarakan, oleh karena itu seorang khatib harus mempunyai kemampuan psikologis, karena tingkat psikologis dan kepribadian seseorang itu berbeda beda.

d. Kemampuan Pengetahuan Kependidikan

e. Kemampuan Pengetahuan Di Bidang Pengetahuan Umum Kemampuan

pengetahuan di bidang pengetahuan umum yang harus dimiliki seorang khatib pada saat ini perkembangan ilmu sangat pesat, apalagi diislam pembangunan seperti sekarang ini masyarakat selalu berkecimpung dalam bidang ilmu teknologi, untuk menghadapi masyarakat seperti sekarang ini diperlukan bagi seorang khatib agar mampu memiliki pengetahuan yang bukan dibidang ilmu agama saja tapi juga pada bidang ilmu lainnya. Khususnya ilmu teknologi dan informasi supaya da'i tidak ketinggalan dan bisa berbaur dengan masyarakatnya.

Esensi khotbah sesungguhnya adalah menyampaikan pesan taqwa, dan inilah yang paling penting dari sebuah khotbah. Pesan taqwa tersebut menghendaki supaya jamaah mengerjakan kebaikan dan menjauhi kejahatan. Untuk mencapai hal itu khatib perlu menerapkan 4 (empat) prinsip retorika sebagai seperti yang dikemukakan oleh Zulhasan Latif, yaitu:

1. Seorang penutur harus pandai memberikan ulasan termasuk ke dalam ulasan argument adalah bukti bukti, contoh, perbandingan, perumpamaan dan lain sebagainya. dalam rangka memenangkan kasus yang menjadi pokok persoalan, penutur harus cakap memilih dan menempatkan ulasan ulasan ini.

2. Penutur harus fasih berbahasa, kelihaian berbahasa seperti, tukar menukar kata kata, istilah dan ungkapan serta mengubah susunan kalimat, merupakan syarat utama dalam retorika sofis. Karena itu, kepastian berbahasa dalam hubungan ini pengertian keahlian bersilat lidah.

3. Penutur harus memanfaatkan emosi penanggap tutur sebaik baiknya. Membangkitkan kepekaan emosi lawan bicara agar mereka kehilangan kejernihan berpikir merupakan salah satu target dalam ajaran retotika sofis. Demikian pula membakar semangat penanggap tutur yang belum memihak perlu dilakukan sehingga akhirnya mereka memihak kepada penutur.

4. Keseluruhan tindak, usaha dan sarana dalam kegiatan bertutur harus diarahkan kepada satu tujuan, yaitu Kemenangan. Karena itu retorika sofis menyarankan membahas persoalan itu sesederhana mungkinBerkaca kepada fenomena yang nampak dalam penyampaian khutbah Jum'at di Masjid Ikhwanul Muslimin Komplek Pegambiran Permai Kota Padang, kebanyakan khatib tidak menerapkan retorika yang baik dalam berkhotbah, tidak memiliki ekspresi atau gaya bahasa yang menarik perhatian mad'u, sehingga apa yang disampaikan khatib tidak bermakna dan tidak dimengerti isi khutbahnya oleh jamaah. 


\section{A. Metodologi Penelitian}

Penelitian tentang retorika khatib dalam penyampaian Khutbah Jum'at di di Masjid Ikhwanul Muslimin Komplek Pegambiran Permai Kota Padang ini menggunakan metode penelitian Kualitatif. Penelitian ini digunakan karena hasil yang dikehendaki adalah data-data deskriptif berupa ucapan dan prilaku khatib Jum'at yang diamati. Uraian tentang ucapan, dan atau prilaku khatib yang diamati, diuangkapkan secara mendalam dan dikaji dari sudut pandang yang utuh dan komprehensif. (Abun Dinata : 2008)

Penelitian ini adalah penelitian lapangan atau field research, oleh karena itu pengumpulan data dilakukan di lapangan, tepatnya di Masjid Ikhwanul Muslimin yang beralamat di Komplek Pegambiran Permai, Kota Padang.

Penelitian kualitatif ini menggunakan informan penelitian sebanyak 8 orang khatib yang melaksanakan khotbah secara bergantian di masjid ikhwanul muslimin Komplek Pegambiran Permai, Kota Padang, dan juga tokoh dan masyarakat di Komplek Pegambiran Permai RW 10, Kota Padang.

Teknik pengumpulan data yang digunakan dalam penelitian kualitatif ini adalah:

1. Observasi

Teknik ini digunakan dalam pengumpulan data dimana peneliti melihat , mendengar, serta merasakan retorika Khatib selama penyampaian Khutbah Jum'at di Masjid Ikhwanul Muslimin. Apa yang disaksikan selama penelitian dicatat, baik di lapangan maupun setelah kembali dari lapangan.
2. Wawancara

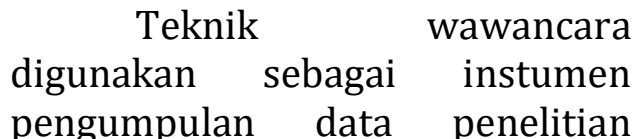
dengan cara tanya jawab sambil bertatap dengan khatib Jum'at setelah khotbah berlangsung. Peneliti menggunakan Interview Guide (Panduan Wawancara) dalam bentuk garis besar saja, sedang perinciannya dilakukan sewaktu terjadi wawancara. Wawancara ini dilakukan bebas dan terbuka kepada khatib yang berjumlah 8 orang khatib, kemudian masyarakat, tokoh masyarakat setempat yang berada di Komplek Pegambiran Permai RW 10 Masjid Ikhwanul Muslimin.

Tekhnik pengolahan data yang digunakan dalam penelitian ini yaitu dengan memeriksa data yang sudah ada, lalu diklasifikasikan data tersebut atau dikelompokkan sesuai dengan jenis masing masing yang diperoleh melalui observasi, wawancara, kemudian menginterprestasikan data berdasarkan yang dipahami, dirumuskan dalam bentuk kalimat. (Moleong : 2011)

\section{B. Hasil Penelitian}

Berdasarkan hasil penelitian ditemukan bahwa Retorika khatib dalam menyampaikan khutbah jum'at di Masjid Ikhwanul Muslimin Komplek Pegambiran Permai Padang dipaparkan sebagai berikut:

\section{Gaya Bahasa Khatib Dalam Penyampaian Khutbah Jum'at Di Masjid Ikhwanul Muslimin Komplek Pegambiran Permai}

Berdasarkan observasi yang dilakukan terhadap Khatib jumat di 
Mesjid Ikhwanul Muslimin Komplek Pegambiran Permai yang menyampaikan khutbah jum'at pada umumnya menggunakan gaya bahasa resmi atau formal. Seperti yang disampaikan oleh ustad Herman Tanjung di bawah ini:

Bapak - bapak dan
saudara - saudara kaum
muslimin sidang jama'ah
jum'at Rahimakumullah.
Adapun pada siang hari
ini, lewat mimbar yang
mulia ini khatib
menghimbau dan
mengajak jema'ah
terutama pribadi khatib
sendiri untuk selalu
meningkatkan iman dan
ketaqwaan kita kepada
Allah. (Herman Tanjung :
2015)

Berdasarkan data di atas khatib jum'at dalam khutbahnya menggunakan gaya bahasa yang baik dan benar sehingga apa yang disampaikannya dapat dipahami dan dimengerti oleh jemaah. Hal ini sesuai dengan pendapat T.A. Lathief Rousydiy yang mengatakan bahwa kemahiran berbicara akan menyebabkan pesan yang disampaikan mudah diterima dan dimengerti oleh mad'unya.( T.A. Lathief Rousydiy : 2005) Jika seorang khatib bisa menggunakan bahasa yang baik dan benar, maka jemaah yang mendengar pun senang dan termotivasi untuk beribadah kepada Allah.

\footnotetext{
Dalam berkhotbah khatib menggunakan bahasa yang bisa dipahami oleh jemaah yang terdiri dari berbagai latar belakang bahasa, yaitu bahasa Indonesia. Berikut ini kutipan khutbah yang disampaikan oleh khatib Herman Tanjung:
}

"Sekali lagi tidak ada manusia yang bernafas yang tidak diuji, maka terima ujian itu. Hadapi ujian itu dengan penuh kesabaran. Nabi Muhammad Saw sabar, mudah mudahan kita menjadi pengikut Nabi Muhammad Saw" (Herman Tanjung : 2015)

Berdasarkan data di atas Khatib Herman Tanjung ini menggunakan bahasa Indonesia yang baik dan benar sehingga jemaah dapat memahami pesan-pesan yang disampaikannya.

Apa maksud dari penggalan bahasa khutbah jum'at tersebut bahwasanya kita hidup di atas dunia ini penuh dengan ujian dan cobaan dari Allah kepada kita, apabila kita sanggup menghadapi ujian yang Allah berikan dengan penuh keikhlasan dan kesabaran maka kita berhasil menempuh ujian, karena pada hakekatnya ujian adalah cobaan bukan siksaan Allah S.W.T. Khatib Herman Tanjung tergolong khatib yang disenangi oleh masyarakat karena bahasanya mudah dimengerti dan dipahami oleh jamaah.

Sedangkan observasi yang penulis lakukan terhadap khatib Gusmardi ketika menyampaikan khutbah Jum'at di Masjid Ikhwanul Muslimin Komplek Pegambiran permai, pada umumnya menggunakan gaya bahasa resmi atau formal, seperti di bawah ini:

Bapak-bapak dan
Saudara- saudara sidang
jema'ah Jum'at yang di
rahmati oleh Allah. Dan
demikianlah khutbah
Jum'at singkat khatib
pada siang hari ini mudah


mudahan bermanfaat bagi kita semua hadir pada siang hari ini terutama diri pribadi khatib sendiri.

Sedangkan observasi penulis terhadap khatib Gusmardi, ia dalam bisa menggunakan bahasa yang baik dan benar juga didalam berkhutbah. Contoh kutipan khutbah jum'at yang disampaikan oleh khatib Gusmardi adalah:

Kita sebagai hamba Allah sepatutnya lah kita bersyukur apa yang telah diberikan oleh Allah. Karena dengan mensyukuri nikmat Allah maka Allah akan menambah nikmat tersebut dan siapa yang tidak mensyukuri nikmat kata Allah maka Allah akan cabut nikmat tersebut dari kita. contohnya saja nikmat saja nikmat jasmani dan rohani. Apabila kita gunakan nikmat Allah dengan baik maka Allah akan menambah nikmat tersebut. Dan sebaliknya apabila kita gunakan nikmat Allah tersebut dengan tidak baik, maka Allah akan mencabutnya kembali nikmat itu dari kita. (Gusmardi : 2015)

Khatib Gusmardi ini mempunyai bahasa yang sangat baik dan bagus yang aktif sebagai khatib di Masjid Ikhwanul Muslimin sehingga jemaah masjid termotivasi dalam mensyukuri nikmat Allah yang telah diberikannya, contoh penggalan bunyi dari isi khutbahnya adalah :" kita sebagai hamba Allah sepatutnya lah kita bersyukur apa yang telah Allah berikan kepada kita umat islam. Karena dengan mensyukuri nikmat Allah maka Allah akan tambah dan siapa yang tidak mau bersyukur Allah akan cabut nikmat itu kembali".

Apa maksud dari penggalan isi khutbah diatas itu yaitu menceritakan tentang kita sebagai umat Islam harus lah kita mensyukuri nikmat Allah. Dan barang siapa yang mensyukuri nikmat Allah maka Allah akan tambah nikmat tersebut dan sebaliknya barang siapa yang mengkufuri nikmat Allah maka adzab Allah amatlah pedih ( Q.S. At Tahrim ayat 7).

Keberhasilan Khatib Gusmardi tidak lepas dari gaya bahasa yang digunakan karena ia merupakan salah satu faktor terpenting dalam retorika. Gaya bahasa yang menarik menyebabkan proses komunikasi berjalan lancar, lancar berarti pesanpesan dakwah yang disampaikan oleh Khatib Gusmardi dapat dipahami dan dimengerti oleh jamaah, apabila ia paham dan mengerti maka ia akan menjalankan ajaran agama yang disampaikan kepada mereka.

\section{Pilihan Kata Khatib Dalam Penyampaian Khutbah Jum'at Di Masjid Ikhwanul Muslimin Komplek Pegambiran Permai.}

$\begin{array}{lrr}\text { Seorang khatib idealnya } \\ \text { mampu melaksanakan } & \text { tugasnya } \\ \text { sebagai pendakwah, } & \text { sehingga } \\ \text { pendengar tertarik dan mengerti } & \text { mang } \\ \text { tentang masalah yang dibahas dengan } \\ \text { menggunakan bahasa yang }\end{array}$
komunikatif, semuanya tidak terlepas dari kata kata yang diucapkan. Kata kata sebaiknya sesuai dengan pemahaman pendengar, karena kata katanya yang tidak efektif akan membuat pendengar menjadi bosan. 
Jika khatib bisa mengemas kata dengan baik, maka pendengar tidak merasa dirinya diajari atau digurui, sebab tidak semua orang setuju berada pada posisi digurui. Seorang khatib yang tidak mampu mengemas dan memilih kata yang akan diucapkan dengan baik, dengan mudah pendengar akan mengetahui kekurangan khatib tersebut. Oleh sebab itu, pemilihan kata sangat mempengaruhi keberhasilan khatib untuk mencapai tujuan yang hendak digapai dari apa yang disampaikan.

Dari wawancara penulis dengan salah seorang jema'ah shalat jum'at yang aktif di Masjid Ikhwanul Muslimin, Buchari berpendapat bahwa dalam berkhutbah yang disampaikan oleh khatib Herman Tanjung,M.Pd diksi dan pilihan katanya sudah baik, serta mudah dipahami. (observasi , Bukhori : 2015)

Berikut ini kutipan khutbah jum'at yang disampaikan oleh khatib Herman Tanjung sebagai berikut:

Rasulullah 63 tahun hidup
dengan umatnya, beliau sudah
berbuat banyak, beliau sudah
menancapkan tongkat tongkat
keislaman. Maka untuk itu, jangan lari
dari ketentuan Allah. Andai kata ada
ujian, andai kata ada cobaan, maka
kembalikan itu semua kepada Allah
SWT. Mudah mudahan kita termasuk
yang senantiasa taat dan patuh
menjalankan perintah Allah SWT.
Maka untuk itu, sekali lagi tidak ada
manusia yang bernapas, ia akan diuji,
maka terima ujian itu, layani, lakukan,
sambut ujian itu dengan penuh
kesabaran, insya Allah bersama orang
orang yang sabar. Nabi Muhammad
Saw sabar dan Allah bersama Nabi
Muhammad Saw. Mudah mudahan
kita pengikut Nabi Muhammad Saw.
Dan sejarah sejarah yang terdapat
didalam Al-Qur'an itu bisa dijadikan

pedoman untuk tidak putus asa dalam kehidupan ini.

Khatib yang satu ini selalu mendapat pujian dari jema'ah shalat Jum'at yang aktif di Masjid Ikhwanul Muslimin, sebab diksi dan pilihan kata yang digunakan oleh khatib ini sebagian besar dianggap sudah tepat menurut jema'ah, Namun ada sedikit kejanggalan dalam cuplikan khutbah tadi yaitu kata penghubung "Tapi" yang seharusnya digunakan pada kata yang kebalikan, yaitu pada kalimat : Rasullulah 63 tahun dengan umatnya, tapi beliau sudah berbuat banyak. Seharusnya kata hubung yang tepat itu adalah kata " Dan" sehingga menjadi "Rasulullah 63 tahun hidup dengan umatnya, dan beliau sudah berbuat banyak. Selanjutnya pada kalimat "Beliau sudah menancapkan nilai nilai keislaman". Kata menancapkan sebaiknya diganti dengan menanamkan agar lebih enak didengar sehingga menjadi "Beliau sudah menanamkan nilai nilai keislaman".

Namun, secara umum diksi
khatib sudah bagus dan khatib
mampu mempertegas hal yang
dianggap penting dalam isi khutbah
dengan memakai kalimat "sekali lagi"
"maka untuk itu, sekali lagi tidak ada
manusia yang tidak diuji, selagi ia
bernapas, ia akan diuji". Penulis juga
melihat kata kata yang disampaikan
khatib Herman Tanjung diatas sudah
mudah dipahami oleh jema'ah, karena
sudah biasa merangkai kata kata
dengan bagus, contohnya seperti
kalimat : "Andaikata ada ujian,
andaikata ada cobaan, maka
kembalikan itu semua kepada Allah
SWT. Mudah mudahan kita termasuk
yang senantiasa taat dan patuh pada
perintah Allah dan kita selalu dibawah
lindungan Allah. Untaian kata khatib
ini cukup mudah dimengerti jema'ah,
apalagi setelah memperjelas kata


ujian dengan cobaan. Selanjutnya khatib juga memakai kata " kita" sehingga jema'ah merasa ada kedekatan batinya dengan khatib tersebut supaya terjalin juga tali silaturahmi kita dengan baik.

Selanjutnya khatib Herman Tanjung juga sangat pandai dalam mempergunakan waktu dengan baik dalam menyampaikan khutbah jum'at dengan melihat situasi dan keadaan jema'ah. Artinya waktu yang dipergunakan oleh khatib Herman Tanjung ini dalam menyampaikan khutbah jum'at sudah baik dan tidak terlalu lama jadi apa yang disampaikan itu sesuai dengan judul yang dibuat dengan konsep yang ada. Tidak terlalu singkat dan tidak terlalu lama dalam memyampaikan khutbah jum'at sehingga jema'ah tidak menjadi bosan dan ngantuk didalam khatib menyampaikan khutbahnya diatas mimbar, jadi apa yang disampaikan oleh khatib Herman Tanjung kepada jema'ah dapat dipahami dengan baik dan benar dan tidak menimbulkan efek negative terhadap jema'ah yang berada di dalam mesjid. Mudah mudahan apa yang disampaikan oleh khatib dapat menjadi pahala dan amal untuk kita di akhirat nanti.

Sedangkan observasi penulis terhadap Gusmardi, ia dalam berkhutbah belum bisa memilih kata kata yang tepat. Salah satu contoh kutipan khutbah yang disampaikan yang berbunyi adalah :

$\begin{array}{lr}\text { Hadirin kaum } & \text { muslimin } \\ \text { Jema'ah } & \text { Jum'at } \\ \text { Rahimakumullah, } & \text { kita } \\ \text { sebagai hamba } & \text { Allah } \\ \text { sepatutnya } \quad \text { lah } & \text { kita } \\ \text { bersyukur apa } & \text { yang } \\ \text { diberikan oleh Allah. Karena } \\ \text { dengan mensyukuri nikmat } \\ \text { yang diberikan oleh Allah } \\ \text { maka Allah akan menambah }\end{array}$

nikmat tersebut. Contohnya saja nikmat kesehatan Jasmani dan rohani, apabila kita gunakan nikmat yang diberikan oleh Allah dengan baik, maka Allah akan menambah nikmat terbebut. Dan sebaliknya apabila kita gunakan nikmat Allah tersebut dengan tidak baik, maka Allah akan mencabutnya kembali nikmat itu dari kita. Namun, kaum muslimin jema'ah Jum'at, setelah Allah memberikan kita nikmat yang banyak, harta dan jabatan yang telah Allah berikan kepada kita, kadang kita lupa atas nikmat Allah yang telah diberikan terhadap kita. Maka Allah akan melaknat orang orang yang mempunyai sifat sifat yang tidak mencerminkan nilai nilai agama. Sehingga nikmat tersebut akan diambil oleh Allah kembali. Sesuai dengan Firman Allah dalam surat At-Tahrim ayat 7. Yang berbunyi. "Apabila engkau mensyukuri nikmat ku kata Allah maka akan aku tambah, dan apabila engkau mengkufuri nikmat ku kata Allah ingat azab Allah sangatlah pedih". (obsevasi, Gusmardi : 2015)

Jika diamati kutipan khutbah Gusmardi diatas, pada paragraph pertama terdapat kalimat kalimat yang susunannya kurang baik. Hal ini mengakibatkan kalimat yang disampaikan oleh khatib Gusmardi agak sedikit sulit dipahami oleh jema'ah. Contoh kalimat kurang utuh itu dari kutipan khutbah diatas adalah " nikmat kesehatan apabila kita gunakan nikmat Allah tersebut 
dengan tidak baik, maka Allah akan mencabutnya kembali nikmat itu dari kita" . sebaiknya khatib mengganti kata " dan" dengan kata penghubung " jika”, sehingga menjadi kalimat utuh dan tidak terputus yaitu "jika sebaliknya apabila kita gunakan nikmat Allah dengan tidak baik, maka Allah akan mencabutnya kembali dari kita.

Selanjutnya kalimat paragraf dua " setelah Allah memberikan kita nikmat yang banyak, harta, jabatan yang Allah berikan kepada kita, kadang kita lupa atas nikmat yang diberikan kepada kita, kadang kita lupa atas nikmat yang diberikan Allah, menurut penulis kurang tepat mengulang kata "kita" karena kalimat tersebut merupakan pemborosan kata dan itu merupakan itu hal yang kurang baik disampaikan karena hal yang seperti itu menjadikan isi khutbah lebih tidak serasi dengan yang semestinya dilakukan oleh khatib. Jadi penulis agak sedikit kurang puas apa yang disampaikan oleh khatib. Sebaiknya kalimat "kita" itu diganti dengan "mereka". Sehingga kalimat tersebut menjadi " Allah memberikan nikmat kepada mereka, mereka lupa atas nikmat itu".

Selain hal hal diatas, dalam khutbah jum'at yang disampaikan oleh khatib Gusmardi juga terdapat banyak sekali pengulangan kata yang diucapkan oleh khatib yang maksud dan tujuannya itu sama. Salah satu contoh kata yang diulang oleh khatib Gusmardi dengan maksud dan tujuannya itu sama adalah " Maka Allah akan melaknat orang orang yang mempunyai sifat sifat yang tidak mencerminkan nilai nilai agama". Kata kata orang, sifat, dan nilai cukup dipakai satu kali saja, sebab ketiga kata maka akan timbul arti yang sama dengan semestinya.
Selanjutnya ketentuan diksi yang tentang pemilihan kata haruslah menarik maka seorang khatib harus memilih kata kata yang menyentuh langsung diri pendengar, menggunakan bahasa yang dibentuk sedemikian rupa sehingga menimbulkan kesan yang indah. Salah satu contoh diksi dan pemilihan kata yang sudah tepat disampaikan oleh khatib Abadi,M.A sebagai berikut :

Wanita yang sholeha dan
suami yang sholeh
merupakan syarat mutlak
untuk mencapai kejayaan
dan kebahagiaan rumah
tangga. Salah satu cirri
wanita sholeha adalah
beriman kepada Allah, ia
melakukan suatu
pekerjaan karena Allah, ia
patuh san taat kepada
Allah dan Rasulnya, dan
ia menjaga dirinya dan
kehormatanya. Bahkan,
dirinci lagi wanita
sholeha itu adalah wanita
yang disiplin dalam
kehidupan, tidak mau
berfoya foya apalagi
mubazir, sabar atas
segala tantangan yang
datang dalam
kehidupannya. Ini cirri
khas wanita sholeha.
(observasi, Abadi : 2015)

Menurut salah seorang jema'ah shalat Jum'at yaitu Khairul, bahwasanya diksi dan pemilihan kata yang digunakan oleh khatib Abadi,M.A diatas sudah tepat, bahasanya mudah dimengerti, serta menyentuh secara langsung ke diri jema'ah.

Selanjutnya pemilihan diksi yang digunakan oleh khatib Iswandi,M.Ag dinilai terlalu sulit dimengerti oleh jema'ah. Berikut 
kutipan khutbah yang disampaikanya

Kalau Allah yang sudah memperjalankan, tidak ada yang jauh bagi Allah, tidak ada yang sulit bagi Allah. Walaupun menurut akal kita ini tidak akan bisa dilakukan oleh akal manusia. Tetapi oleh manusia yang pilihan Allah, yang mana Nabi Muhammad Saw, Rasul, Nabi terakhir,la nabi ya $b a^{\prime} d a$, tidak ada lagi nabi setelah Nabi Muhammad Saw. Suatu perjalanan yang luar biasa itu yang beliau tempuh dalam hanya beberapa jam saja. Katakanlah kalau kita lihat hanya semalam saja, sedangkan perjalanan dari Masjidil Haram ke Masjidil Aqsa itu akan menempuh berbulan bulan dengan berjalan kaki dengan onta. (Observasi, Iswandi, 2015)

Dari kutipan diatas terlihat bahwa pengulangan pengulangan yang dilakukan oleh khatib Iswandi membuat isi khutbah menjadi sulit dipahami. Seperti pada kalimat “ Tetapi oleh manusia pilihan Allah, yang mana Nabi Muhammad Saw, Rasul, Nabi yang terakhir, la nabi ya $b a^{\prime} d a$, tidak ada lagi nabi setelah Nabi Muhammad Saw. Maksud dan tujuan nya hanyalah satu yaitu Rasulullah Saw tetapi hampir semua gelar nabi dibaca oleh khatib dan sepertinya kalimat itu menggantung ketika khatib sudah sampai pada titik. Ini membuat keraguan bagi jemaah karena kalimat khatib yang sulit dipahami dan tidak sampai ke ujung kalimat.

Berdasarkan
observasi penulis terhadap
khatib Iswandi di Masjid
Ikhwanul Muslimin Komplek
Pegambiran Permai dalam
menyampaikan khutbah Jum'at
pada umumnya menggunakan
pilihan kata yang resmi atau
formal. Seperti yang
disampaikan oleh khatib
Iswandi adalah:

Asalamualaikum

warahmatullahi

wabarakatuh,

Alhamdulillah

Alhamdulillah Hirabbil

Allamin, Puji dan syukur atas kehadirat Allah SWT

yang telah melimpahkan

Rahmat dan Karunianya

kepada kita semua

sehingga dapat hadir

pada siang hari ini di

masjid dalam rangka

melaksanakan ibadah

Shalat Jum'at, shalawat

beserta salam kita

sampaikan kepada Nabi

kita yakninya Nabi

Muhammad SAW, yang

telah membawa kita dari

zaman kebodohan

kepada zaman yang

berilmu pengetahuan

seperti kita rasakan pada

saat sekarang ini.

(Obsevasi, Iswandi, 2015)

Dari kutipan diatas terlihat bahwa pengulangan pengulangan yang dilakukan oleh khatib Iswandi membuat isi khutbah menjadi sulit dipahami. Seperti pada kalimat " Tetapi oleh manusia pilihan Allah, yang mana Nabi Muhammad Saw, Rasul, Nabi yang terakhir, la nabi ya $b a$ 'da, tidak ada lagi nabi setelah Nabi Muhammad Saw. Maksud dan tujuan nya hanyalah satu yaitu Rasulullah Saw tetapi hampir semua gelar nabi 
dibaca oleh khatib dan sepertinya kalimat itu menggantung ketika khatib sudah sampai pada titik. Ini membuat keraguan bagi jemaah karena kalimat khatib yang sulit dipahami dan tidak sampai ke ujung kalimat.

Disamping itu terlihat pemakaian beberapa kata hubung yang dinilai tidak tepat pada kutipan khutbah diatas, seperti : penggunaan kata "dalam hanya beberapa jam " Hanya beberapa jam saja". Selanjutnya pemakaian kata "dengan" yang diulang dua kali seharusnya satu kali, seperti : menempuh berbulan bulan dengan berjalan kaki dengan onta. Akan lebih enak di dengar dan mudah dipahami jika khatib mengatakan " menempuh berbulan bulan berjalan kaki dengan onta"

Selanjutnya susunan kata yang tidak tepat juga terdapat dalam kutipan kalimat berikut :

Perjalanan yang jauh itu tentu ada lika likunya yang dilakukan oleh Nabi Muhammad Saw. Ada beliau shalat bersama dengan nabi nabi, ada baliau melihat suatu perjalanan yang akan terjadi kelak kepada umat Nabi Muhammad Saw, orang yang sudah tidak sanggup lagi menahan beban ditambah lagi bebannya. Itu yang kita dengar, yang kit abaca didalam peristiwa isra' dan mi'rajnya Nabi Muhammad Saw.

Khatib seharusnya mendahulukan subjek pada kalimat " Perjalanan yang jauh itu ada lika likunya yang dilakukan Nabi Muhammad Saw" agar lebih mudah dimengerti oleh jema'ah dan lebih enak didengar, maka khatib seharusnya menyatakan " Perjalanan jauh yang dilakukan oleh Nabi Muhammad Saw itu tentu ada lika likunya. Begitu juga dengan kalimat sesudahnya yaitu : "Ada beliau shalat bersama dengan nabi, ada beliau melihat suatu perjalanan yang akan terjadi kelak umat Nabi Muhammad Saw". Sebaiknya khatib tetap mendahulukan subjek agar kalimat khatib enak didengar, sehingga menjadi : Beliau ada shalat dengan Nabi nabi, beliau ada melihat suatu perjalanan yang akan terjadi kelak kepada umat Nabi Muhammad Saw".

Maka dengan banyaknya pengulangan pengulangan kalimat yang dilakukan oleh khatib Iswandi serta tidak bisa menggunakan diksi dan pemilihan kata yang tepat, hal ini membuat isi khutbah yang disampaikan menjadi panjang dan sulit dipahami. Akibatnya khatib yang satu ini terkenal bagi jema'ah untuk mendengarkan isi khutbah dan juga tidak bisa mempergunakan waktu dengan tepat dan efektif dalam berkhutbah, sehingga tidak dapat merespon dan menimbulkan kebosanan bagi jema'ah untuk mendengarkan isi pesan khutbah yang disampaikan oleh khatib tersebut diatas mimbar.

Hal ini sesuai dengan pendapat Junaidi yang disampaikan kepada penulis, yaitu jema'ah shalat jum'at yang aktif di Masjid Ikhwanul Muslimin. Kalau khatib menyampaikan khutbah jum'at itu adalah khatib Iswandi, saya merasa terlalu lama waktunya sehingga menimbulkan kebosanan untuk mendengarkan isi khutbahnya dengan baik. (Observasi, Junaidi, 2015)

diatas mimbar knatib harus mempersiapkan bahan bahan atau konsep yang akan disampaikan kepada jema'ah termasuk juga pemilihan kata kata. Dan kata kata itu hendaklah terlebih dahulu dipilih dan 
dikemas sedemikian rupa menimbulkan daya tarik bagi siapa saja yang mendengarkannya. Sebaliknya kata kata yang tidak dipilih terlebih dulu jika disampaikan kepada jema'ah, maka tidak akan terawasi itu akan mengakibatkan sesuatu yang fatal. Dan karena memilih kata juga harus mempertimbangkan kebutuhan khalayak. Karena jika sesuatu yang menyebabkan kebutuhan seseorang terpenuhi, maka sesuatu itu akan dicari dan ditunggu. Begitu juga dengan khutbahnya. Jika khutbah sesuai dengan kebutuhan jemaah maka secara otomatis akan dinanti dan diikuti. Maka semua itu tidak akan terlepas dari kata atau gagasan, pemilihan kata, makna kata, kalimat maupun juga pemilihan judul atau topik pembahasan dan disini juga terdapat peran diksi. Pemilihan kata yang tepat dan menyentuh diri jemaah secara langsung juga tergambar dari isi khutbah yang disampaikan oleh khatib Marjoli, S.Ag. berikut isi kutipan khutbahnya :

Ada tata cara sholat yang khusyuk. Kapan waktu khusyuk itu datang pada kita? Apa bila kebimbangan didalam hati kita sudah tidak ada lagi, apabila dosa kita semakin hari semakin habis. Tapi yang jelas bapak dan saudara kaum muslimin jemaah jum'at, yang paling penting kita jaga adalah kelalaian dari segi waktu, kedua kelalaian dari segi syarat dan rukun shalat itu tersebut. Tapi yang dikatakan khusyuk itu hanya diantara kita dengan Allah. Jadi kapan khusyuk itu datang? Jawabannya adalah tergantung kepada diri kita yang hidup masing
masing.(Observasi, Marjoli, 2015)

Dari bahasa yang disampaikan khatib Marjoli, S.Ag terdapat 2 pertanyaan yang langsung berkaitan dengan pribadi jemaah. Namun, tujuan pertanyaan tersebut bukanlah untuk meminta jawaban secara lisan dari jemaah melainkan dengan pertanyaan itu jemaah merasa lebih tersentuh dan mempertanyakan kekhusukan dirinya ketika shalat, sebab pada pertanyaan kedua, khatib menyatakan bahwa jawabanya ada pada diri kita masing masing. Dengan demikian, diksi yang digunakan oleh Marjoli,S.Ag menurut penulis sudah tepat karena bahasanya mudah dipahami serta mengandung kedekatan emosi dengan jemaah melalui pertanyaan tadi.

Hal ini juga sesuai dengan pendapat yang disampaikan salah seorang jemaah yang aktif di Masjid Ikhwanul Muslimin kepada penulis yaitu Rusli. Bahwasanya khutbah jum'at yang disampaikan oleh khatib Marjoli sangat mudah untuk memahami isi pesannya, karena pilihan kata yang digunakan oleh khatib sudah tepat dan enak didengar oleh jemaah jum'at yang ada di dalam masjid ini. Hal ini sesuai dengan pendapat Gorys Keraf bahwa berdasarkan pilihan kata, gaya bahasa mempersoalkan kata mana yang paling tepat dan sesuai untuk posisiposisi tertentu dalam kalimat, serta tepat tidaknya penggunaan kata-kata dilihat dari lapisan pemakaian bahasa dalam masyarakat. Dengan kata lain, gaya bahasa ini mempersoalkan ketepatan dan kesesuaian dalam menghadapi situasi-situasi tertentu. (Wawancara, Rusli, 2015)

\section{Nada Khatib Dalam Penyampaian Khutbah Jum'at Di Masjid Ikhwanul}




\section{Muslimin Komplek Pegambiran Permai}

Intonasi adalah irama atau tangga nada yang jika diibaratkan dengan nyayian begitu juga dengan khutbah jum'at. Karena didalam khutbah tersebut irama dan juga variasi suara agar tidak terjadi kebosanan bagi orang yang mendengarkannya. Tinggi rendahnya nada akan mempengaruhi daya tangkap pendengaran yang juga menghasilkan dinamika suara yang akan memicu indra pendengaran kita. Seorang khatib harus bisa menguasai ilmu tentang variasi suara serta gelombang suara yang dikeluarkan ketika berkhutbah. Sebab intonasi (Nada) merupakan salah satu penyebab berhasil tidaknya dengan penyampaian pesan.

Dalam intonasi ada nada tinggi dan juga ada nada rendah. Ketepatan penggunaaan intonasi dalam menyampaikan khutbah akan memunculkan daya tarik jemaah yang pada intinya akan memperhatikan dan mengamalkan pesan yang disampaikan. Jika penggunaan intonasi tidak pada tempatnya atau tidak sesuai dengan apa yang diinginkan maka pesan dakwah sulit juga diterima oleh jemaah bahkan ada yang ditolak oleh jemaah.

Intonasi merupakan suatu cara untuk mengungkapkan kata kata dengan baik agar pesan yang disampaikan tidak mengalami kerancuan pada jemaah yang mendengarkannya. Intonasi berfungsi sebagai penentu di dalam menyampaikan khutbah jum'at, karena dengan sajian kata yang baik akan diterima dengan cara yang baik pula.

Penerapan informasi dalam khutbah jum'at merupakan salah satu bentuk dari retorika. Dalam retorika khatib dituntut untuk bisa mengendalikan audien dan menyajikan hal hal yang menarik dan menyenangkan. Pesan khutbah jum'at yang disajikan dengan intonasi dan berbagai variasi dan menarik akan mudah diterima dan mudah dipahami, tetapi sebaliknya jika pesan khutbah disampaikan maka pesan khutbah yang disampaikan dengan sajian intonasi yang tidak ada bervariasi dan kurang menarik maka pesan khutbah tersebut sulit untuk diterima.

Menurut Junaidi salah seorang jemaah shalat jum'at yang aktif di masjid Ikhwanul Muslimin mengatakan bahwa penerapan intonasi oleh khatib dalam penyampaian khutbah jum'at di Masjid Ikhwanul Muslimin itu sangat bervariasi bentuknya. Ada yang menerapkan nada tinggi dan sedang, ada yang rendah dan ada juga yang nadanya datar sama sekali. Seperti yang disampaikan oleh khatib Marjoli,S.Ag dalam khutbahnya, ia menerapkan intonasi tinngi ada yang sedang ada pula yang rendah sampai tidak kedengaran oleh jemaah jum'at. Ketika suara tinggi isi pesanya tentang larangan perbuatan adu domba, berzina, minuman keras, berjudi, serta azab yang akan diterima jika melakukan apa yang dilarang tersebut. Sedangkan suara datar dan rendah, pesan khutbahnya, berisika tentang ajakan untuk berbuat baik, beramal sholeh, bagi yang mengerjakan kebaikan tersebut. Suara tinggi yang dilakukan oleh khatib Marjoli,S.Ag tidaklah melebihi batas pendengaran dan tidak menimbulkan permasalahan bagi jemaah. Artinya apa intonasi tinggi yang dilakukan oleh khatib Marjoli,S.Ag tidak berlebihan dan tidak menimbulkan kebisingan tetapi ketinggian suaranya dalam batas atau tataran yang wajar. Sedangkan intonasi yang rendah yang 
disampaikan dalam batas yang wajar pula, bisa didengarkan dengan baik dan juga dengan jelas.

Pada saat saat tertentu dalam khutbahnya khatib Marjoli,S.Ag juga melakukan jeda(berhenti sejenak). Dalam khutbahnya yang memakai jeda Marjoli,S.Ag terapkan penegasan terhadap isi pesan yang dianggap penting disampaikan dengan mengulang ngulang kata yang dianggap penting tersebut. (wawancara, Junaidi, 2015)

Adapun penerapan intonasi yang datar saja yang dilakukan oleh khatib Eko Seprianto,M.A dalam khutbahnya. Beliau dalam menyampaikan khutbah jum'at dengan nada yang datar dan lemah tanpa memperhatikan variasi suara. Walaupun isi khutbahnya itu berupa larangan, yang membutuhkan intonasi nada yang tinggi atau keras untuk menguatkan isi pesan yang disampaikan. Namun khatib Eko Seprianto tetap saja menyampaikan isi pesan khutbahnya dengan nada yang datar. (wawancara, Seprianto, 215)

Halim adalah salah seorang jemaah shalat jum'at di Masjid Ikhwanul Muslimin mengungkapkan kepada penulis bahwa intonasi khatib Eko Seprianto dalam menyampaikan khutbahnya jum'at datar dan terkesan monoton, sehinnga jemaah merasa loyo dan tidak bersemangat untuk mendengarkan khutbah jum'at yang disampaikan oleh khatib tersebut.(wawancara, Halim : 2015)

Dalam observasi yang penulis
lakukan terhadap khatib Eko
Seprianto dalam menyampaikan
khutbah jum'at, Eko Seprianto
memang menggunakan nada datar
tanpa memperhatikan variasi suara.
Sewaktu khatib menyampaikan pesan

ajakan, penyampaian masih datar juga dan begitu juga dalam penyampaian tentang larangan Allah SWT, ketika khatib tetap menggunakan nada datar tanpa ada menarik turunnya nada suaranya. Penulis melihat khatib Eko Seprianto belum bisa menguasai audien atau jemaah shalat jum'at sewaktu berkhutbah. Hal ini beranjak dari kelemahan diri khatib sendiri, karena khatib tidak ada menggunakan intonasi dan variasi suara dalam penyampaian khutbah jum'at tersebut.

Sehingga masih ada diantara jemaah kita shalat Jum'at yang acuh tak acuh saja ketika khatib telah berkhutbah dan juga sampai tertidur. Ini ditandai dengan intonasi dalam penyampaian pesan yang digunakan oleh khatib Eko Seprianto datar dan berkesan monoton, dan penyampaian yang monoton itu akan menimbulkan kebosanan dan melanggar kebiasaan pendengaran kebanyakan orang. (Observasi, Eko Seprianto, 2015)

Hal ini juga dari pendapat salah seorang jemaah Masjid Ikhwanul Muslimin yaitu Agus dan juga mengatakan kepada penulis, bahwasanya selama khutbah khatib Eko Seprianto nada datar dari awal hingga akhir khutbah karena kurang mengesankan bagi jemaah untuk mendengarkanya, jadi isi khutbah nya itu kurang antusias jemaah untuk memahaminya karena suaranya itu kadang nggak kedengaran karena nggak jelas jadi akhirnya jemaah pun ada yang tertidur ada yang acuh tak acuh aja saat khatib berkhutbah.

Selanjutnya dalam observasi yang penulis lakukan terhadap khatib Warlan Sukandar,M.A juga beberapa pemakaian intonasi sudah tepat. Walaupun Warlan Sukandar menyampaikan khutbah beraneka ragam bentuknya atau berbagai 
macam variasi intonasi yang dilontarkan, dan khatib ini mempunyai nada yang tinggi dan tegas dalam menyampaikan khutbah sehingga melebihi pendengaran yang jelas dan keras. Apalagi ketika jemaah melihat khatib yang satu ini mereka akan paham apa yang disampaikan khatib. Padahal intonasi Warlan Sukandar ini sangat tinggi dan juga ada yang nada sedang serta nada rendah ketika mau kalimat kalimat akhir. Jadi penulis melihat khatib ini ada beberapa jemaah yang merasa paham apa yang disampaikannya karena suara yang dikeluarkannya tegas dank eras sehingga jemaah tersebut tidak bosan atau tidak jenuh dalam menghadapi khatib diatas mimbar. Kadang kadang ada kalimat yang samar samar karena begitu ketika rendahnya suara khatib sehingga jemaah agak sedikit kurang semangat kalau nada suara nya itu kurang jelas. (Observasi, warlan Sukandar : 2015)

Ketika penulis melakukan wawancara kepada salah seorang jemaah Masjid Ikhwanul Muslimin yaitu Kamaluddin ia mengatakan bahwa khatib tersebut memiliki nada yang tinggi yang digunakan khatib Warlan Sukandar pada awal khutbah khatib menyampaikan wasiat taqwa kepada jemaah dengan suara yang kurang tinggi, sehingga jemaah jadi merasa bertafakur, menunduk kepada Allah yang bunyinya "Inni ussikum waiya ya bitaqwallah ha fagad' fazal muntaqun, ittakullah ha haqkatukhotih walla tamutunna illa waantum muslimun". Selain itu intonasi Warlan Sukandar isi khutbah nya sangat baik, ketika khatib memberikan intonasi tinggi malah jemaah tidak ada yang ngantuk seakan akan isi khutbah nya itu sangat menarik jemaah , apalagi ketika khatib menyampaikan intonasi tinggi maka akan menjadi lebih santai nggak bosan atau jenuh.(Observasi kamaluddin,2015)

Berbeda dengan intonasi yang digunakan khatib Ihsan,S.Ag dalam menyampaikan khutbahnya, juga berdasarkan observasi penulis, khatib Ihsan sudah tepat dalam penggunaan intonasi (Tinggi Rendahnya Nada). Serta ada juga penekanan kata yang dianggap sangat penting. Seperti dalam kutipan khutbahnya sebagai berikut:

Allah sangat menyayangi dan meninggikan derajat orang orang yang selalu beriman dan bertagwa kepada Allah dan serta berbakti kepada kedua orang tua. Namun barang siapa yang selalu menghormati orang tua maka Allah akan memuliakan mereka. Dan janganlah kamu sekali kali melawan, menghardik, mengatakan Ah, Cis kepada kedua orang tua, karena itu merupakan dosa yang paling besar disisi Allah dan Allah akan mengazab manusia yang selalu membantah, melawan perintah orang tua. Dan didalam surat Al Isra' ayat 23, yang artinya : " Dan Tuhanmu telah memerintahkan agar kamu tidak menyembah selain dia dan berbuat baik kepada ibu bapakmu. Jika salah seorang diantara keduanya atau dua duanya sampai berusia lanjut dalam pemeliharaanmu, maka sekali kali janganlah engkau mengatakan keduanya dengan perkataan "Ah" dan jangan engkau membentak keduanya, dan ucapkanlah kepada keduanya perkataan yang baik." Dan itu merupakan dosa yang tidak dapat diampuni oleh Allah SWT. (Observasi, Ihsan, 2015)

Dari uraian isi khutbah diatas, Khatib Ihsan,S.Ag sudah bisa 
menggunakan intonasi dan penekanan penekanan yang baik dan tepat terhadap nada yang pantas untuk nada tinggi dan nada rendah didalam khatib berkhutbah. Hal ini sesuai yang diungkapkan oleh salah seorang jemaah jum'at Masjid Ikhwanul Muslimin yaitu Rahmad kepada penulis yang telah mendengarkan khutbah jum'at yang disampaikan oleh khatib Ihsan,S.Ag tersebut. Sebagai mana pendapat yang diungkapkan oleh Rahmad terhadap khatib Ihsan,S.Ag dibawah ini:

Saya sangat merasa senang kalau saya shalat jum'at di Masjid Ikhwanul Muslimin seandainya yang menyampaikan khutbah itu adalah Ihsan,S.Ag, karena isi khutbahnya itu sangat fakta atau suatu kejadian, dan juga isi khutbah itu tertuju kepada akhlak kepada orang tua, seperti selalu melakukan apa yang diperintahkan oleh orang tua terhadap kita dan jangan sekali kali kamu melawan kepada kedua orang tuamu dan tidak akan melakukan hal hal yang tidak terpuji kepada ibu bapak, karena dialah yang mengandung, melahirkan, mendidik, dan membesarkan kita dari kita masih kecil sampai kita dewasa. Kemudian disamping itu intonasi yang jelas yang digunkan oleh khatib ini sangat menyentuh hati, kalau memang akhlak kepada orang tua dengan baik, khatib Ihsan menggunakan nada yang tinggi dan keras saat dia berkhutbah, tetapi sebaliknya ada larangan larangan Allah yang disampaikan sesuai yang ada di dalam Surat Al Isra' ayat 23 yang diatas dan sudah diterangkan juga dengan sangat jelas dan padat. Artinya tidak ada menimbulkan kebosanan bagi pendengaran jemaah, sehingga jemaah jum'at merasa sangat menunduk dan menandahkan kedua tangan meminta kepada Allah. Dan mudah dipahami isi khutbahnya yang disampaikannya.(observasi, Rahmad, 2015) Data-data diatas sesuai dengan pendapat Gorys Keraf yang mengatakan gaya bahasa berdasarkan nada didasarkan pada sugesti yang dipancarkan dari rangkaian kata-kata yang terdapat dalam sebuah wacana. Sering kali sugesti ini akan lebih nyata kalau diikuti dengan sugesti suara dari pembicara, bila sajian yang dihadapi adalah bahasa lisan.

\section{Struktur Kalimat Khatib dalam penyampaian Khutbah Jum,at di Masjid Ikhwanul Muslimin}

Struktur kalimat disini adalah bagaimana tempat sebuah unsur kalimat yang dipentingkan dalam kalimat tersebut. Ada kalimat yang bersifat periodik, bila bagian yang terpenting atau gagasan yang mendapat penekanan ditempatkan pada akhir kalimat. Ada kalimat yang bersifat kendur, yaitu bila bagian yang terpenting mendapat penekanan ditempatkan pada awal kalimat. Bagian bagian yang kurang penting atau semakin kurang penting dideretkan sesudah bagian yang dipentingkan tadi. Dan jenis yang ketiga adalah kalimat berimbang, yaitu kalimat yang mengandung dua bagian kalimat atau lebih yang kedudukannya sama tinggi atau sederajat.

Khatib Abadi,M.A mempunyai susunan kalimat yang baik dan benar didalam cara dia berkhutbah dia menggunakan alur maju sehingga didalam berkhutbah dia tidak membolak balikan kalimat yang telah dia ucapkan. Contoh isi kalimat khutbah yang disampaikan oleh khatib Abadi,M.A adalah:

Istri yang sholeha dan suami yang sholeh merupakan syarat mutlak untuk mencapai kejayaan dan kebahagiaan rumah tangga. 
Dan salah satu ciri istri sholeha adalah beriman kepada Allah. Ia melakukan suatu pekerjaan karena Allah, ia patut dan taat kepada Allah dan Rasulnya. Dan ia menjaga dirinya dan kehormatannya.( Observasi, Abadi : 2015)

Dan maksud dari kutipan khutbah diatas adalah istri yang sholeha adalah pakaian suami yang sholeh dan sebaliknya suami yang sholeh adalah pakaian istri yang sholeha. Dan itu merupakan suatu cerminan bagi kaum laki laki dan perempuan yang belum menikah atau contoh yang baik kepada yang belum punya istri atau suami.

Menurut salah seorang jemaah shalat jum'at yaitu khairul bahwasanya khatib Abadi, M.A ini mempunyai susunan kalimat yang baik dan benar. Dan juga mempunyai alur maju sehingga dapat mudah dipahami.

Sedangkan khatib Iswandi,
M.Ag juga mempunyai susunan
kalimat yang baik dan bagus. Dia
dalam berkhutbah khatib ini sangat
paham dan kalimatnya sangat tertuju
kepada topik judul khutbah jum'at.
Contoh kutipan khutbah jum'at yang
disampaikan oleh khatib Iswandi,
M.Ag adalah:

Kalau Allah yang sudah memperjalankan kita, tidak ada yang jauh lagi dari Allah, tidak ada yang sulit bagi Allah. Walaupun menurut akal kita ini tidak akan bisa dilakukan oleh akal manusia. Tetapi oleh manusia pilihan Allah, yang mana Nabi Muhammad Saw, Rasul, Nabi terakhir, la nabi ya $b a^{\prime} d a$ yang artinya tidak ada nabi sesudahnya (Nabi Muhammad Saw).(Iswandi : 2015)
Maksud dari isi kutipan khutbah diatas yang disampaikan khatib Iswandi,M.Ag bahwasanya segala apa yang lakukan diatas dunia atau di bumi ini tidak ada yang sulit bagi Allah hanya sekedar membalikkan telapak tangan kalau kata Allah Kun Fayakun "terjadi maka terjadilah" contohnya nikmat yang Allah berikan kalau kata Allah diambil maka tidak sulit bagi Allah untuk mengambil nikmat tersebut dari manusia.

Dan menurut salah seorang jemaah Masjid Ikhwanul Muslimin yaitu Rizky bahwasanya struktur kalimat yang digunakan oleh khatib itu sudah cukup bagus dan benar sehingga kalimat yang dia pakai tidak terlalu susah untuk dipelajari. Dan kalimat nya mudah juga mempunyai alur maju.

Sedangkan khatib Marjoli.S.Ag juga mempunyai struktur kalimat yang sama dengan khatib yang lainnya yaitu kalimatnya yang baik dan teratur dalam menyampaikan khutbahnya. Berikut ini kutipan isi khutbah khatib Marjoli.M.Ag adalah:

Ada tata cara shalat yang khusyuk. Kapan kita khusyuk itu datang pada kita? apabila ada kebimbangan dalam hati kita sudah tidak ada lagi, apabila dosa kita semakin hari semakin habis. Tetapi yang paling penting di dalam shalat adalah tidak boleh lalai dalam mengerjakan shalat baik dari segi waktu dan yang kedua kelalaian dari segi syarat dan rukun shalat itu tersebut.(Observasi, Marjoni : 2015)

Maksud dari isi kutipan
khutbah diatas adalah yang
disampaikan oleh khatib Marjoli.S.Ag
adalah bagaimana kita melaksanakan


shalat yang baik dan benar menurut ajaran islam yaitu dengan kekhusyukan kita didalam shalat. Maka kita khusyuk kita dalam menjalankan ibadah shalat maka Allah akan menilai kita sebagai hambanya yang sholatnya baik dan benar dan juga kita tidak boleh lalai dalam shalat apalagi meninggalkan shalat tersebut.

Dan menurut salah seorang jemaah shalat jum'at yaitu ilham bahwasanya khatib Marjoli.S.Ag ini mempunyai susunan kalimat yang baik dan teratur dan cara dia berkhutbah tenang dan tidak tergesa gesa sehingga jelas kalimat yang dia sampaikan kepada jemaah di Masjid Ikhwanul Musilimin.

\section{KESIMPULAN}

\begin{abstract}
Retorika khatib dalam penyampaian khutbah jum'at di Masjid Ikhwanul Muslimin Komplek Pegambiran Permai Kelurahan Ampalu Nan XX Kecamatan Lubuk Begalung Kota Padang ditinjau dari Gaya Bahasa khatib sudah lebih baik dan bagus. Dan kebanyakan para jema'ah agak kurang memahami apa gaya bahasa yang digunakan oleh khatib dalam berkhutbah supaya lebih baiknya isi khutbah maka para khatib harus lebih memantapkan gaya bahasa yang dipakai dalam berkhutbah agar Mad'u paham dan mengerti.
\end{abstract}

Retorika khatib dalam penyampaian khutbah Jum'at di Masjid Ikhwanul Muslimin Komplek Pegambiran Permai Kelurahan Ampalu Nan XX Kecamata Lubuk Begalung Kota Padang ditinjau dari diksi khatib sudah ada yang menerapkan diksi dan pemilihan kata dengan baik dan bagus. Akan tetapi sebagiannya lagi masih ada yang belum mengerti dan paham tentang diksi dan pemilihan kata dan menerapkan kata kata yang bisa dijadikan pedoman dalam berkhutbah. Dan bahasa sangat menentukan juga dalam keberhasilan khatib dalam menyampaikan khutbah jum'at.

Retorika khatib dalam penyampaian khutbah jum'at di Masjid Ikhwanul Muslimin Komplek Pegambiran Permai Kelurahan Pegambiran Ampalu Nan XX Kecamatan Lubuk Begalung Kota Padang ditinjau dari sudut Intonasi khatib ini bentuknya beraneka ragam modelnya dan ada yang berkhutbah dengan nada tinggi dan ada yang menengah dan ada yang rendah. Akan tetapi sebagian lagi masih ada juga yang belum paham apa Intonasi atau Nada dalam berkhutbah.

Retorika khatib dalam penyampaian khutbah jum'at di Masjid Ikhwanul Muslimin Komplek Pegambiran permai Kelurahan Ampalu Nan XX Kecamata Lubuk Begalung Kota Padang ditinjau dari Struktur Kalimat yang dipakai oleh khatib sudah agak cukup bagus dan baik tapi klau bisa khatib memakai kalimat yang lebih bagus dan baik serta memahami isi khutbah sehingga para Mad'u paham dan juga mengerti apa saja kalimat yang baik dan yang di patut disebutkan dalam berkhutbah.

\section{DAFTAR PUSTAKA}

Abd. Rauf, Abdul Qadir Said, Dirasah fid da'wah Islamiah, Kairo: Dar El Tiba'ah Almahmadiyah, 1987, cet 1

Al -Qhatani, Sa'id, menjadi Da'i yang sukses, Jakarta: Qisti Press, 2005

Amin, Samsul Munir, Ilmu Dakwah, Jakarta: Amzah, 2009

Amin, Samsul, Munir, Ilmu Dakwah Jakarta: Amzah, 2009 
Anwar, Gentasari, Retorika Prektis tekhnik dan Seni Berpidato Jakarta : Rineka

Aziz, Moh Ali, Ilmu Dakwah, Jakarta : Kencana: 2009

Basuki, I Gusti Ngurah Oka, Retorika Kiat Bertutur, Malang : YA 3 1990

Cangara, Hafied, Lintasan Sejarah Ilmu Komunikasi, Surabaya: Usaha Nasional 1998.

Departemen Agama RI, Al-Qur'an dan Terjemahannya, Dipenegoro: 2005

Effendi, Onong Uchjana, Ilmu Komunikasi Teori dan Praktek, Bandung: Remaja Rosdakarya 1986

Firma RIMBOW 1995

Ismail, ilyas dan Hotman, Prio, Filsafat Dakwah: Rekayasa membangun agama dan peradaban islam, Jakarta: Surau, 2011

Lexy J. Moleong, Metode Penelitian Kualitatif, Bandung: Remaja Rosdakarya, 2010

Nata Abuddin, Metodologi Studi Islam, PT Raja Grafindo Persada, Jakarta: 2012

Natsir , Tohir M, Dakwah dan Pemikirannya, Jakarta : Gema Insani, 1999

Nurgiyantoro, Teori Pengkajian fiksi, Yogyakarta: Gadjah Mada University Press, 2007, hlm 295

Rousydiy, TA Lathief, Dasar Dasar Retorika Komunikasi dan Informasi, Medan:

Saeful Muhtadi, Asep, Safei Ahmad, Agus, Metode Penelitian Dakwah, Bandung: Pustaka Setia, 2003
Salmadanis, Metode dakwah Perspektif AlQur'an, Padang: Hayfa Press, 2010

Siddiq, Samsuri, Dakwah dan Tekhnik Berkhutbah, Jakarta: Alma'rif, 1981

Sunarjo dan Djoenaesih S.Sunarjo, Komunikasi Persuasi dan Retorika,

Suparta, Drs. H. Munzier, Metode Dakwah, Prenada Media Group, Jakarta: Kencana, 2009

Yogyakarta : Liberty, 1983

Yusuf, Zainal, Abidin, Pengantar Retorika, Bandung: Pustaka Setia,cet 12013. 